\title{
Influence of the ground-water level on the botanical composition and productivity of intensively managed grassland on heavy clay soil
}

\section{Hoogerkamp and J. J. Woldring}

Research and Advisory Institute for Field Crop and Grassland Husbandry (P.A.W.), P.O. Box 33, Wageningen, The Netherlands

Received 1 September, 1966

\section{Summary}

On a heavy river-clay soil the influence of the ground-water level on the gross yield of old grassland and leys was studied. The ground-water levels showed a clear but variable effect on the grass production. In periods with a precipitation excess and in many springs the yield was highest on the deepest drained plots. In dry periods, however, the yield decreased with an increasing depth of drainage. In the first-mentioned periods the variation in the grass yields was caused by a difference in the nitrogen supply to the crop, in the dry periods the water supply to the plant was the main growth limiting factor.

With grazing, grass growth as well as the utilization of the grass grown, were unfavourably affected by a high ground-water level in wet periods.

The botanical composition of the sward gradually changed under influence of the ground-water level. However true moisture or drought indicators did not occur.

\section{Introduction}

The water supply is important for grassland. Grass growth may be influenced by this water supply directly (water supply to the plants) as well as indirectly (influencing other growth factors). The most favourable water supply for grass growth is determined by contradictory demands; the risk of water shortage will decrease with a more excessive water supply in the soil, but there will be a greater risk of unfavourable effects on the soil aeration and all kinds of physical properties of the soil. If however, the moisture supply is decreased, the aeration of the soil will be better, but the risk of water shortage will increase.

The utilization of the grass and the health of grazing cattle can also be influenced by the moisture conditions in the soil. In general grassland is more tolerant of an excessive water supply than arable crops. Usually however, it needs a more liberal water supply, because of its rather shallow root system and its long growing period.

The depth of the ground-water level only partly determines the water supply to the grass; precipitation, precipitation distribution, moisture-holding capacity of the soil, capillary conductivity, etc. are important as well. Therefore the optimal ground-water 
level usually varies from place to place and, in a variable climate, from season to season.

With the large-scale land consolidation of the river-clay district in the mid-Netherlands, there was a great need for more detailed information on the influence of the depth of the ground-water level on the productivity of grassland and various arable crops. In 1953 a large experimental field was therefore set out in this area to study the problem in more detail. The results of the first five years have been published by Minderhoud (1960).

\section{Dutch climate}

Precipitation in The Netherlands usually exceeds the evapotranspiration during a great part of the year; the reserve only takes place during the growing season (Table 1). Even if the precipitation during the growing season should be completely utilized, on an average there should still be a water shortage in this period. This deficit, however, varies widely from year to year.

Table 1 Average monthly potential evapotranspiration of a short sward (calculated with Penman's formula for a free water surface and multiplied by 0.8 ) and the average monthly precipitation in $\mathrm{mm}$, over the years 1931-1965

\begin{tabular}{lrrrrrrrrrrrrrr}
\hline & $J$ & $F$ & $M$ & $A$ & $M$ & $J$ & $J$ & $A$ & $S$ & $O$ & $N$ & $D$ & $\begin{array}{c}\text { Total } \\
\text { April- } \\
\text { Sept. }\end{array}$ \\
& & & & & & & & & & & & & & \\
Precipitation & 64 & 51 & 43 & 47 & 51 & 58 & 74 & 76 & 59 & 62 & 65 & 63 & 713 & 365 \\
Evapotranspiration & 4 & 14 & 34 & 61 & 86 & 99 & 92 & 76 & 48 & 22 & 8 & 3 & 547 & 462 \\
Precipitation deficit & -60 & -37 & -9 & 14 & 35 & 41 & 18 & 0 & -11 & -40 & -57 & -60 & -166 & 97 \\
\hline
\end{tabular}

\section{Experimental design}

The ground-water level experimental field was set out on river-clay soil (basin clay; Edelman, 1950). This soil is very heavy and has a considerable moisture-holding capacity.

Table 2 Organic matter content, granular composition and amount of water available between pF 2.0 and $p F 4.2$ in the soil of the experimental field

\begin{tabular}{|c|c|c|c|c|c|}
\hline & $\begin{array}{c}\text { Layer } \\
(\mathrm{cm})\end{array}$ & $\begin{array}{c}\text { Organic } \\
\text { matter } \\
(\%)\end{array}$ & Sand $\underset{(\%)}{(>16 \mu)}$ & Silt $\underset{(\%)}{(<16 \mu)}$ & $\begin{array}{c}\text { Moisture available } \\
\text { (\%) }\end{array}$ \\
\hline Old grassland & $\begin{array}{l}0-5 \\
5-10\end{array}$ & $\begin{array}{l}25 \\
12\end{array}$ & $\begin{array}{l}15 \\
13\end{array}$ & $\left.\begin{array}{l}60 \\
75\end{array}\right\}$ & 33 \\
\hline & $10-20$ & 6 & 14 & $80^{\prime}$ & 23 \\
\hline & $20-50$ & 2 & 5 & 93 & 17 \\
\hline Arable field & $0-25$ & 5 & 13 & 82 & $?$ \\
\hline
\end{tabular}


In this experimental field differences in the ground-water table were obtained by pumps, ditches provided with spill-over dams and drain tiles. The experimental field was divided into four parts: two fields with permanent grassland, one field with arable crops and one field with apple trees. (In this paper only the results of the permanent grassland and of the leys, sown on the arable field, are reported.)

Each of the two fields with old grassland consisted of five plots, with different water levels:

- The plots of one field had constant water levels of $25,40,65,95$ and $140 \mathrm{~cm}$ below the surface, respectively.

- The plots of the other field had alternating water levels. From 1954-1959 the water levels in the period May-August were $40,40,40,40$ and $140 \mathrm{~cm}$ below the surface and during the remaining months $40,65,95,140$ and $140 \mathrm{~cm}$, respectively. From 1960 to 1964 the levels in the period December-May were 25, 25, 95 and $140 \mathrm{~cm}$ below the surface and during the remaining months $95,140,140$ and $140 \mathrm{~cm}$; next to these water levels the combination 40-95 from the period 1954-1959, was maintained.

The five water tables maintained on the arable field were also constant, viz. 40, 50, 65,95 and $140 \mathrm{~cm}$ below the surface.

The old grassland was grazed by cattle or sheep and mown once a year. The gross grass yield per ground-water level was determined on plots protected by cages. These plots were mown five times a year. The cages were moved to another part of the plot each year. The leys were exclusively cut and that on the same time of determining the yields on the permanent grassland.

Besides the gross yields, the botanical composition and bearing capacity of the sward were also studied.

\section{Results}

\section{Botanical composition}

The moisture supply may considerably affect the botanical composition of a sward, because altogether different species will occur under wet conditions than under dry ones. The botanical composition of a sward gives a good indication of the moisture conditions in the soil (Kop, 1965).

Gradual changes in the botanical composition also took place on the experimental field under influence of differences in the ground-water level, but here true moisture or drought indicators (de Vries and de Boer, 1959) did not occur (Table 3).

These and the other results show that on this well fertilized and intensively managed grassland the changes in the botanical composition, related to the ground-water level, are small: Alopecurus pratensis was stimulated by lowering the water level (probably this was caused by the better nitrogen supply on these plots; see p. 137), and Agrostis stolonifera by raising the water table.

The botanical composition on the plots with a high water table, however, is somewhat flattered; in wet periods when especially the bearing capacity on these plots was very low, grazing and with this, trampling and puddling was reduced as much as possible.

On extensively managed grassland on the same soil type the botanical composition clearly reacts to the ground-water level. On fields with a ground-water level of 40-70 $\mathrm{cm}$ below the surface the botanical composition was generally good. With increasing 
Table 3 Botanical composition in percentages by weight in 1953 (just before the beginning of the experiment) and in 1964 (the last experimental year). The figures mentioned are the averages of the data obtained in analyses of April, June and September

\begin{tabular}{|c|c|c|c|c|c|c|c|c|c|c|}
\hline \multirow[b]{3}{*}{ Grass species } & \multicolumn{10}{|c|}{ Ground-water level ( $\mathrm{cm}$ below the surface) } \\
\hline & \multicolumn{5}{|c|}{1953} & \multicolumn{5}{|c|}{1964} \\
\hline & 25 & 40 & 65 & 95 & 140 & 25 & 40 & 65 & 95 & 140 \\
\hline Lolium perenne & 32 & 23 & 31 & 47 & 47 & 12 & 26 & 18 & 20 & 23 \\
\hline Festuca pratensis & 4 & 6 & 20 & 4 & 9 & 5 & 2 & 1 & + & - \\
\hline Phleum pratense & 1 & 1 & 0 & 1 & 1 & 11 & 7 & 8 & 8 & 7 \\
\hline Poa pratensis & 2 & 1 & 1 & 0 & t. & $\div$ & + & 4 & 5 & 3 \\
\hline Poa trivialis & 2 & 8 & 1 & 3 & 3 & 13 & 10 & 5 & 6 & 7 \\
\hline Alopecurus pratensis & 16 & 13 & 8 & 7 & 3 & 15 & 16 & 34 & 41 & 42 \\
\hline Agrostis stolonifera & 4 & 5 & 1 & 3 & 2 & 24 & 21 & 9 & 6 & 8 \\
\hline Festuca rubra & 8 & 11 & 9 & 3 & 1 & - & 4 & 12 & 7 & 4 \\
\hline Holcus lanatus & 11 & 4 & 12 & 8 & 17 & + & 1 & 1 & + & + \\
\hline Cynosurus cristatus & 6 & 6 & 6 & 3 & 3 & - & 1 & - & - & + \\
\hline Other grass species & 6 & 7 & 7 & 5 & 1 & 11 & 6 & 3 & 6 & 4 \\
\hline Dicotyledons & 8 & 15 & 4 & 16 & 13 & 9 & 6 & 5 & 1 & 2 \\
\hline
\end{tabular}

Table 4 Average dry-matter and crude-protein yields obtained on the old grassland with constant ground-water tables. Yields in tons per ha per year. The nitrogen fertilization was $70 \mathrm{~kg} \mathrm{~N}$ per ha per year

\begin{tabular}{lccccc}
\hline & \multicolumn{5}{c}{$\begin{array}{c}1954-1964 \\
\text { Ground-water }\end{array}$} \\
\cline { 2 - 5 } & 25 & 40 & 65 & 95 & 140 \\
& 9.35 & 8.95 & 9.39 & 9.06 & 9.41 \\
Dry-matter yield & 1.46 & 1.41 & 1.55 & 1.59 & 1.66 \\
Crude-protein yield & & & & & \\
\hline
\end{tabular}

or decreasing depth of drainage many drought or moisture indicators, respectively, were found in the sward (Minderhoud et al., 1960). By intensifying the management of this grassland the botanical composition seems to indicate the moisture conditions of the soil less clearly; it is however also possible that the more constant groundwater level of the experimental field had influence.

Gross yields

By averaging all yields, obtained on the old grassland with constant ground-water levels during the experimental period, it was found that the dry-matter yields were hardly affected by the difference in the ground-water level, whereas the crude-protein yields mainly were higher as the ground-water table was lower (Table 4).

This may imply that the ground-water level hardly affected grass growth on this heavy clay soil. However, it is also possible that the effect of the ground-water level did not clearly show, because yields, obtained in periods with entirely different moisture supplies were averaged. The yields of shorter growing periods show that the lastmentioned is the case; the ground-water level has a very clear but variable effect 
on grass growth. The shortest periods of which yield data are known, are the five week periods (the first cut was harvested at the end of April or the beginning of May, whereas the four subsequent cuts were always harvested 5 weeks after). The following periods may be distinguished with regard to the effect of an increasing depth of drainage on the gross yields:

a) Periods with decreasing yields.

b) Periods with increasing yields.

c) Periods in which the yields were not clearly affected.

The response variations are caused by differences in the precipitation available to the grass. Attempts were made with various moisture-determination methods (nylon units and gypsum blocks) to express this relation in figures, but reliable results were not obtained. The yield differences were therefore compared to the precipitation and evapotranspiration figures from a weather station in the neighbourhood of the experimental field. This comparison clearly showed that the precipitation deficit (or excess) during grass growth as well as in the preceding periods is a significant factor. This was also the conclusion of many other research workers (see Minderhoud, 1960).

Decreasing yields with an increasing depth of drainage. This response to the groundwater level occurs in periods in which the moisture supply, originating from the precipitation, is insufficient (dry periods).

The fairly great precipitation excess during the winter months provides the soil with sufficient water at the beginning of the growing season to enable undisturbed grass growth. However, the available moisture content in the soil generally decreases with the advancing growing season (usually there is a precipitation deficit in the growing season) and the risk of water shortage will increase. Despite the large moistureholding capacity of this clay soil grass growth is often unfavourably affected by a water shortage in the summer months and all the more so if the soils are deeply drained. Because water excess seldom occurs in mid-summer, the yields in this period (3rd and 4th cut) are on an average lower with an increasing depth of drainage (Table 5).

Table 5 Relative dry-matter yields of the 3rd and 4th cuts (growing period half June until half August). The yields of the plot drained to $25 \mathrm{~cm}$ have been put at 100. Nitrogen fertilization was $10 \mathrm{~kg} \mathrm{~N}$ per ha per cut

\begin{tabular}{lrrrrr}
\hline & \multicolumn{5}{c}{$\begin{array}{c}1954-1964 \\
\text { Ground-water level (cm below }\end{array}$} \\
& 25 & 40 & 65 & 95 & 140 \\
& 100 & 89 & 82 & 77 & 78 \\
3rd cut & 100 & 94 & 99 & 88 & 89 \\
4th cut & & & & & \\
\hline
\end{tabular}

In these dry periods the crude-protein content of the dry-matter was always higher with an increasing depth of drainage, and because of this the crude-protein yield was also unfavourably affected by water shortage, though to a less extent, than the dry-matter yield. Makkink (1960) found the same results. 
It is striking that the yield depressions resulting from a deeper ground-water level occur throughout the range of $25-95 \mathrm{~cm}$; deeper drainage does not further decrease the yield. Whether a ground-water table of $25 \mathrm{~cm}$ in dry periods is already too low to produce an optimal yield could not be established from the results obtained.

The sudden occurrence of water shortage on old grassland is mainly caused by the superficial root system. Young grassland having a much deeper root system is some. what less susceptible to drought (Table 6).

Table 6 Relative dry-matter yields of one year old perennial ryegrass grass (sown in the autumn of the preceding year) and of the old grassland in dry periods. Nitrogen fertilization $40 \mathrm{~kg} N$ per ha per cut

\begin{tabular}{lcccc}
\hline & \multicolumn{5}{c}{$\begin{array}{c}1957,1961 \text { and } 1963 \\
\text { Ground-water level (cm below }\end{array}$ the surface) } \\
\cline { 2 - 5 } & 40 & 65 & 95 & 140 \\
Old grassland & $100^{1}$ & 86 & 74 & 74 \\
Ley & $100^{2}$ & 93 & 92 & 92
\end{tabular}

1 Actual yield was 14.2 tons per ha

2 Actual yield was 15.8 tons per ha

Table 7 Relative nitrogen effect ${ }^{1}$ and nitrogen output 2 when nitrogen fertilization is increased from $10 \mathrm{~kg} \mathrm{~N}$ per ha per cut to $60 \mathrm{~kg}$ (in periods in which the dry-matter yield increased as the depth of drainage decreased)

\begin{tabular}{lccccc}
\hline & \multicolumn{5}{c}{ Ground-water level (cm below the surface) } \\
\cline { 2 - 6 } & 25 & 40 & 65 & 95 & 140 \\
Nitrogen effect & 100 & 99 & 35 & 29 & 21 \\
Nitrogen output & 100 & 105 & 60 & 57 & 40 \\
\hline Increase in the dry-matter yield as a result of the nitrogen applied \\
2
\end{tabular}

The depression of grass growth in the dry periods in summer could theoretically be decreased to a large extent by periodically resowing the grassland. Considering the expenses, resow risks and yield losses involved, however, this should not be a practical solution.

In dry periods a nitrogen application on the old grassland showed an enhancing effect on the yield differences observed, because the nitrogen effect and to a less extent the nitrogen output were generally higher with a higher ground-water table (Table 7).

All these results show that in dry periods in summer the grass growth is unfavourably influenced by a low ground-water level. A high ground-water level in these periods could prevent this unfavourable effect. Since long-term weather forecasts are (as yet) not reliable and the ground-water level in this heavy soil only gradually 
adjusts itself to the water table in the ditches, this would imply that a high groundwater level should be maintained in summer. However, this again involves disadvantages in the spring and in wet periods. The plot with a high ground-water level during the period April to August and a low one during the remaining time of the year therefore produced the same yield as the plots with a constantly high or a constantly low water table.

This is contradictory to the current opinion that a high ground-water level in summer, combined with a low one during the remaining part of the year, should produce the highest yield (e.g. Klapp, 1954). Desiccation of this clay soil during the summer seems to have a favourable effect on grass growth.

On the field with the varying ground-water levels it was also found that a high ground-water level out of the growing season has hardly any effect on the productivity of the sward during dry periods in the summer; it was only affected when the water shortage occurred in very early summer.

This high ground-water level out of the growing season had however a distinctly negative effect on the productivity of the grassland in spring.

In the Dutch climate an optimal water supply for grassland on this heavy clay soil is impossible to attain by the ground water only. To obtain a higher productivity of the sward in dry periods during summer, sprinkling or flooding should be applied as has been suggested by Minderhoud (1960).

Increasing yields with an increasing depth of drainage. The grassland yield was often favourably affected by a deeper drainage in spring as well as in periods with an excessive water supply during the remaining part of the growing season.

In spring the yield of the first cut was higher with a lower ground-water table in most years (Table 8).

This agrees with an observation in grassland farming that in spring wet soils are late. The yield-increasing effect of a low ground-water table in spring is larger for the crude-protein yield than for the dry-matter yield. In individual years the size of the yield depression of the first harvest, grown with a high ground-water level varied considerably. The cause of this differing reaction is not quite clear, but there are indications that grass growth is most harmed by a high ground-water table in cold springs.

The unfavourable influence of a high ground-water level on grass growth in spring is, however, not only the result of this high level during this period. On the field with the varying ground-water tables it was found that a high ground-water level

Table 8 Relative dry-matter and crude-protein yields obtained in spring (first cuts 1955-1964). The yields of the plot with a ground-water level of $25 \mathrm{~cm}$ and fertilized with $30 \mathrm{~kg} \mathrm{~N}$ have been put at 100

\begin{tabular}{|c|c|c|c|c|c|c|c|c|c|c|}
\hline \multirow{2}{*}{$\begin{array}{l}\text { Nitrogen fertili- } \\
\text { zation (in spring): } \\
\text { Ground-water level } \\
\text { (cm below the surface): }\end{array}$} & \multicolumn{5}{|c|}{$30 \mathrm{~kg} \mathrm{~N} / \mathrm{ha}$} & \multicolumn{5}{|c|}{$60 \mathrm{~kg} \mathrm{~N} / \mathrm{ha}$} \\
\hline & 25 & 40 & 65 & 95 & 140 & 25 & 40 & 65 & 95 & 140 \\
\hline Dry-matter yield & 100 & 94 & 109 & 127 & 125 & 112 & 110 & 133 & 143 & 140 \\
\hline Crude-protein yield & 100 & 93 & 125 & 141 & 139 & 122 & 123 & 152 & 172 & 166 \\
\hline
\end{tabular}


(40 $\mathrm{cm}$ below the surface) in summer (May-August) combined with a low one (95$140 \mathrm{~cm}$ below the surface) during the remaining part of the year, caused a yield depression with the first harvest of almost the same size as a constantly high level (40 $\mathrm{cm}$ below the surface). In addition it was found that a very high ground-water table $(25 \mathrm{~cm}$ below the surface) during the period that the cattle was housed (the end of November until the first harvest) combined with a low one $(95-140 \mathrm{~cm}$ below the surface) during the remaining part of the year, in most years had the same unfavourable effect on grass growth in spring, as a high ground-water table in summer (MayAugust) and a low one in the remaining part of the year.

There are no indications that the effect of the nitrogen applied in spring was influenced by the differences in the depth of drainage (Table 8). Only on the $25 \mathrm{~cm}$ drained plot the nitrogen effect was somewhat lower.

It should be considered that all plots were fertilized at the same time; in practice, however, the drier fields often are first dressed.

In the wet periods: on the old grassland with the constant ground-water tables, grass growth was also better in the periods of the growing season with a relatively large precipitation excess with a deeper drainage. The unfavourable effect of high groundwater tables was more distinct in the crude-protein yield than in the dry-matter yield (Table 9).

Table 9 Relative dry-matter and crude-protein yields obtained in wet periods. Nitrogen fertilization was $10 \mathrm{~kg} \mathrm{~N}$ per ha per cut. The yield of the plot with a ground-water level of $25 \mathrm{~cm}$ has been put at 100

\begin{tabular}{lccccc}
\hline & \multicolumn{5}{c}{ Ground-water level (cm below the surface) } \\
\cline { 2 - 6 } & 25 & 40 & 65 & 95 & 140 \\
Dry-matter yield & 100 & 103 & 129 & 128 & 141 \\
Crude-protein yield & 100 & 111 & 149 & 161 & 174 \\
\hline
\end{tabular}

Table 10 Relative nitrogen effect and nitrogen output when nitrogen fertilization is increased from $10 \mathrm{~kg} \mathrm{~N}$ per ha per cut to $60 \mathrm{~kg}$ (in wet periods during the growing season)

Ground-water level ( $\mathrm{cm}$ below the surface)

\begin{tabular}{lccccc} 
& \multicolumn{6}{c}{ Ground-water level (cm below the surface) } \\
\cline { 2 - 6 } & 25 & 40 & 65 & 95 & 140 \\
Nitrogen effect & 100 & 273 & 436 & 405 & 252 \\
Nitrogen output & 100 & 236 & 479 & 486 & 357 \\
\hline
\end{tabular}

With a lower ground-water level the nitrogen fertilizer applied was generally better utilized in these wet periods. The plot with the lowest ground-water level was the only exception to this (Table 10).

Dry-matter yields not clearly affected by differences in ground-water level. This occurred in a few springs (4 out of 11) and in periods with moderate precipitation 
deficit or excess. The crude-protein yield was indeed stimulated by an increasing depth of drainage.

\section{Net grass yields}

Although only the gross yields were determined on the experimental field it was clearly evident during the grazing of the grassland that the bearing capacity and with it the grazing losses were also affected by the depth of drainage (Table 11).

This difference in bearing capacity resulted in trampling of the sward and puddling of the soil, when the plots with a high ground-water level $(25$ and $40 \mathrm{~cm})$ were grazed in wet periods. (This unfavourable effect is only partly expressed in the gross yields obtained, for the cages remain in the same place for one year.)

The disadvantage of a poor bearing capacity increased with a more intensive grassland use. To limit the trampling and puddling, the ground-water level in this heavy clay soil should be at least $65 \mathrm{~cm}$ below the surface.

Table 11 Bearing capacity in $\mathrm{kg} / \mathrm{cm}^{2}$, estimated with a penetrometer

\begin{tabular}{rrrrrr}
\hline Date & \multicolumn{5}{c}{ Ground-water level (cm below the surface) } \\
\cline { 2 - 5 } & 25 & 40 & 65 & 95 & 140 \\
& & & & & \\
$6-11-1962$ & 8.3 & 6.0 & 11.6 & 13.6 & 12.0 \\
$14-11-1962$ & 5.8 & 6.2 & 11.0 & 12.0 & 12.6 \\
$28-3-1963$ & 5.4 & 9.6 & 11.7 & 16.6 & 15.3 \\
$21-11-1963$ & 8.4 & 9.8 & 10.1 & 10.5 & 9.9 \\
& & & & &
\end{tabular}

\section{Causes of the yield differences}

The ground-water level may influence grass growth in many different ways. Not only the water supply to the grass is influenced, but to a greater or less extent the aeration, temperature and structure of the soil as well. Differences in aeration, temperature and structure may influence plant growth not only directly, but also indirectly by affecting many microbiological (e.g. nitrification, mineralization, denitrification) and chemical processes (e.g. reduction of $\mathrm{Fe}^{+++}$to $\mathrm{Fe}^{++}$and $\mathrm{Mn}+++$ to $\mathrm{Mn}^{++}$) important to plant growth. Finally, also the extent to which various nutrients leach and thus are lost to plant growth are probably affected by the ground-water table.

It could not be accurately determined how the ground-water level affected grass growth in the discussed experimental field. It was, however, found that in addition to the water supply to the grass, especially its nitrogen supply was clearly affected by differences in the ground-water level. The nitrogen fertilization was therefore varied. In the following these two factors (water and nitrogen supply) will be discussed in detail.

Decreasing yields with an increasing depth of drainage (dry periods)

In dry periods during the summer the dry-matter yields decreased with an increasing 
depth of drainage; the crude-protein content of the dry-matter, however, nearly always increased with an increasing depth of drainage.

Fig. 1 shows the crude-protein and dry-matter yields obtained in some of these dry periods plotted against the nitrogen applied in the same periods and also the drymatter yield against the crude-protein yield.

These and other available data show that the dry-matter and crude-protein yields in these periods are unfavourably affected by a low ground-water table, and that the dry-matter yield, with an equal nitrogen yield (crude-protein yield), was larger as the ground-water level was higher. This implies that the dry-matter production was more affected by water shortage than nitrogen uptake and indicates, that the yield depressions on old grassland resulting of an increased depth of drainage are caused in the first place by a direct water shortage of the grass plants.

The reason of the decrease in nitrogen yield with an increasing depth of drainage is not quite clear. Some of the possibilities are: a decreased uptake capacity of the

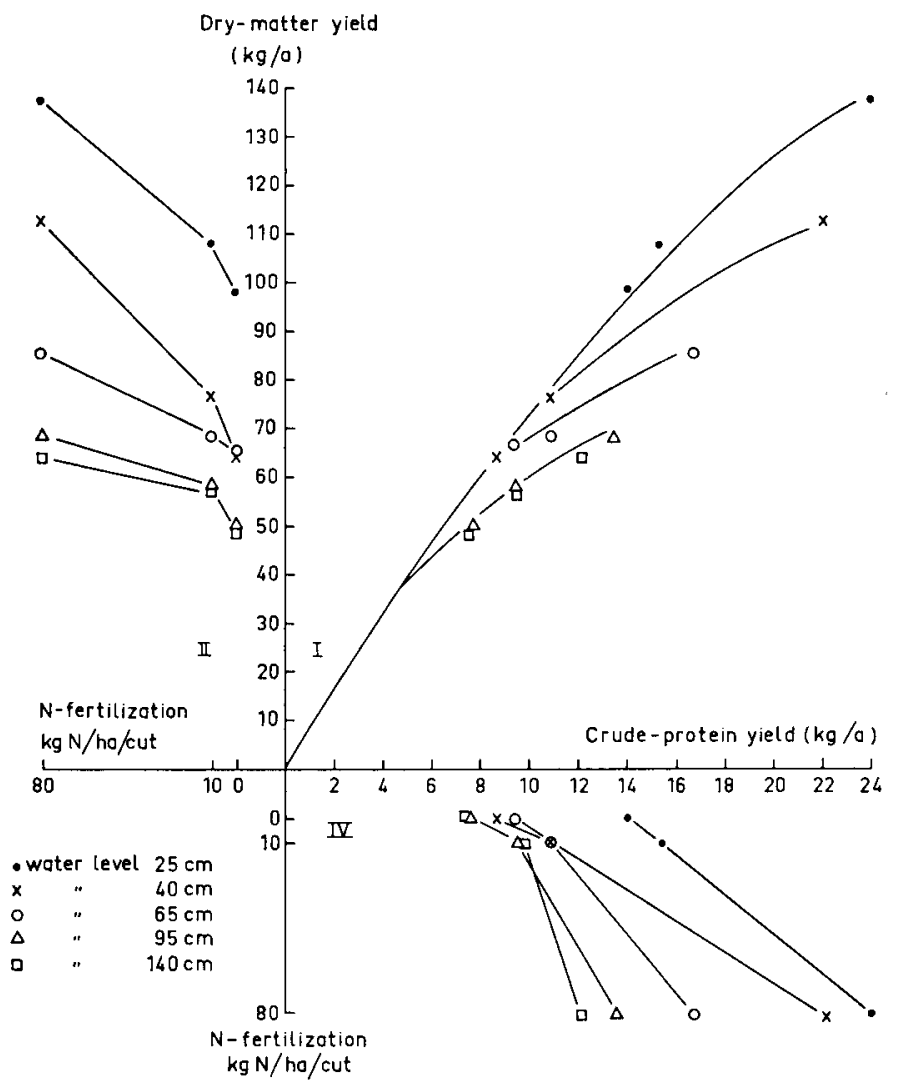

Fig. 1 Relation between nitrogen fertilization and dry-matter yield (quadrant II), nitrogen fertilization and crude-protein yield (quadrant IV), as well as between dry-matter and crude-protein yields (quadrant I) in some dry periods (since the nitrogen fertilization was not the same during the whole experimental period, not every dry period could be included in this figure). 
roots, decreased solubility of the nitrogen in the soil and decreased nitrogen mineralization.

On the leys yield depressions occurred only in extreme drought; the reason for this is not exactly clear, because of the small number of observations. However, the impression is gained that the growth depression is mainly caused by a decreased nitrogen supply on the deeper drained treatments. As a result of the relatively deep root system the water required can be taken up from the deeper soil layers, but it is too dry for a sufficient nitrogen uptake, for nitrogen is mainly taken up from the top soil. This trend, however, was not always clear; occasionally not the nitrogen uptake was unfavourably affected, but the dry-matter production per unit of nitrogen taken up.

Increasing yields with an increasing depth of drainage (springs and wet periods) In spring. In seven experimental years out of eleven the yield of the first harvest was higher with a lower ground-water level. This holds for the crude-protein yield as well as the dry-matter yield. These yield differences may have been caused by the difference in the botanical composition between the plots: the percentage of Alopecurus pratensis, a species with an early spring growth, was larger as the groundwater table was lower. The yield differences, however, do not always correspond with these percentages whereas on the leys consisting mainly of perennial ryegrass, similar yield differences occurred (Table 12).

Table 12 The dry-matter yield ( $\mathrm{kg} / \mathrm{are}$ ) in the spring of 1963 (first cut)

\begin{tabular}{|c|c|c|c|c|c|}
\hline \multirow{2}{*}{$\begin{array}{l}N \text {-fertilization } \\
\text { in the spring } \\
(\mathrm{kg} \mathrm{N} / \mathrm{ha})\end{array}$} & \multirow[t]{2}{*}{$\begin{array}{l}\text { Type of } \\
\text { grassland }\end{array}$} & \multicolumn{4}{|c|}{$\begin{array}{c}\text { Ground-water level } \\
\text { (cm below the surface })\end{array}$} \\
\hline & & 40 & 65 & 95 & 140 \\
\hline 30 & old grassland & 13.2 & 21.5 & 20.7 & 21.6 \\
\hline 30 & ley & 13.2 & 21.7 & 20.7 & 23.7 \\
\hline 60 & old grassland & 17.8 & 25.0 & 28.8 & 31.6 \\
\hline 60 & ley & 19.7 & 27.6 & 24.1 & 27.4 \\
\hline
\end{tabular}

In Fig. 2 it is shown that at the permanent grassland the dry-matter production at an equal nitrogen yield (crude-protein yield) was almost the same at all treatments. In these springs the nitrogen uptake is the limiting factor for the grass growth; the nitrogen uptake decreased with a decreasing depth of drainage. Minderhoud (1960) suggested that this difference in nitrogen uptake was mainly caused by a stimulated denitrification by a higher ground-water level. However, this does not seem plausible in this case, because then the utilization of the fertilizer nitrogen applied should have been lower with a higher ground-water table as well. Since the nitrogen applied is taken up at almost the same rate, the differences in nitrogen are more likely the result of differences in uptake of soil nitrogen. This may be caused by a decrease in the mineralization rate and/or in the amount of rooted soil with a decreasing depth of drainage.

Sieben (1964) determined the nitrate production in the soil of a ground-water table experimental field. This took place on a number of plots kept free of plant growth. 


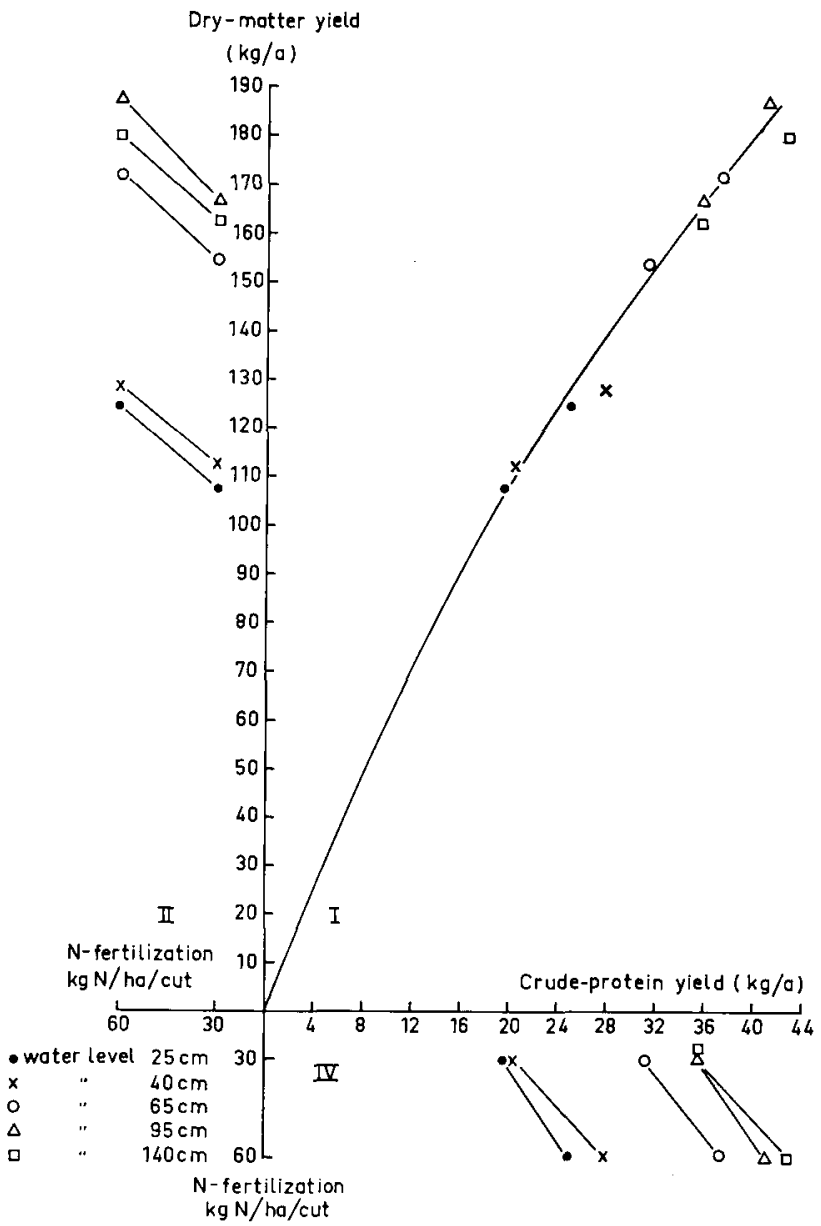

Fig. 2 Relation between nitrogen fertilization and dry-matter yield, nitrogen fertilization ana crudeprotein yield as well as between crude-protein and dry-matter yield in springs (first cuts) in which grass growth decreased as the depth of drainage decreased.

He found that more nitrate nitrogen was present with an increasing depth of drainage. This suggests that the nitrogen mineralization is harmed by a high ground-water table. However, it is difficult to determine to what extent this decreased mineralization is directly caused by a high ground-water level in spring, with the resulting poor aeration and lower temperature. The impression is gained, however, that there is an indirect effect of the ground-water table as well. On the plots, with a low ground-water level in autumn, winter and spring and with a high one only in summer, the nitrogen supply in spring was also poor and with it grass growth. For a good nitrogen supply in spring, these heavy clay soils apparently should desiccate somewhat in summer. This drought effect is, however, again eliminated by a high ground-water table in winter. 


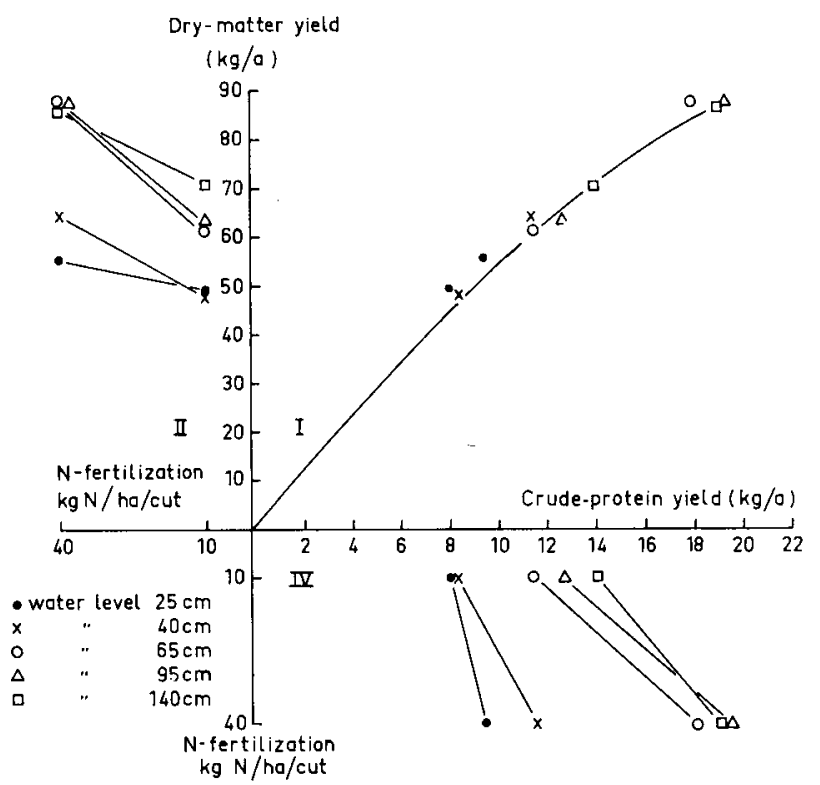

Fig. 3 Relation between nitrogen fertilization and dry-matter yield, nitrogen fertilization and crudeprotein yield and between dry-matter and crude-protein yield in wet periods.

In wet periods. Like in spring the decreased yield, obtained with a high water level, is the result of a decreased nitrogen uptake (Fig. 3).

In this case not only the uptake of soil nitrogen decreases with a decreasing depth of drainage, but the output of the fertilizer nitrogen is also decreased. In this case it could not be established what caused the difference in nitrogen uptake. Next to a difference in mineralization and amount of rooted soil, differences in uptake rate of the roots, leaching and denitrification may be important as well.

Dry-matter yields not clearly affected by differences in ground-water level In these periods the nitrogen content in the dry matter generally increased with an increasing depth of drainage. Because the dry-matter yield did not increase with an increasing depth of drainage it is likely that the dry-matter production was affected by water shortage.

\section{Acknowledgement}

The auther's thanks are due to miss A. H. van Rossum for translating the manuscript.

\section{References}

Edelman, C. H., 1950. The soils of The Netherlands. Amsterdam.

Klapp, E., 1954. Wiesen und Weiden. Berlin. 
Kop, L. G., 1965. Moisture indication on grassland by vegetation and soil: a comparison of maps. Neth. J. Agric. Sci., 13 (1): 6-20.

Makkink, G. F., 1960. Het stikstofgehalte van het gras in samenhang met de vochttoestand van de grond. Jaarb. I.B.S. Wageningen, 1960, pp. 101-107.

Minderhoud, J. W., 1960. Grasgroei en grondwaterstand. Thesis, Wageningen.

Minderhoud, J. W., Krist, G. en Woldring, J. J., 1960. De grondwaterstand en zijn betekenis voor bruto-opbrengst, beworteling en botanische samenstelling van komkleigrasland. Meded. 43: P.A.W., Wageningen.

Sieben, W. H., 1964. Invloed van de ontwateringstoestand op de stikstofhuishouding en opbrengst. Landbouwk. Tijdschr., 76: 784-802.

Vries, D. M. de and Boer, Th. A. de, 1959. Methods used in botanical grassland research in The Netherlands and their application. Herbage Abstr., 29 (1) : 1-7. 